\title{
The Usefulness of Neutrality
}

Julia Jones Zawatsky, MD

Sheppard and Enoch Pratt Hospital, Towson Maryland

Follow this and additional works at: https://jdc.jefferson.edu/jeffjpsychiatry

Part of the Psychiatry Commons

Let us know how access to this document benefits you

\section{Recommended Citation}

Zawatsky, MD, Julia Jones (1987) "The Usefulness of Neutrality," Jefferson Journal of Psychiatry. Vol. 5 : Iss. 2 , Article 5.

DOI: https://doi.org/10.29046/JJP.005.2.002

Available at: https://jdc.jefferson.edu/jeffjpsychiatry/vol5/iss2/5

This Article is brought to you for free and open access by the Jefferson Digital Commons. The Jefferson Digital Commons is a service of Thomas Jefferson University's Center for Teaching and Learning (CTL). The Commons is a showcase for Jefferson books and journals, peer-reviewed scholarly publications, unique historical collections from the University archives, and teaching tools. The Jefferson Digital Commons allows researchers and interested readers anywhere in the world to learn about and keep up to date with Jefferson scholarship. This article has been accepted for inclusion in Jefferson Journal of Psychiatry by an authorized administrator of the Jefferson Digital Commons. For more information, please contact: JeffersonDigitalCommons@jefferson.edu. 


\title{
The Usefulness of Neutrality
}

\author{
Julia Jones Zawatsky, M.D.
}

Recently, the idea of therapeutic neutrality has been attacked. Many observers have suggested that the neutral therapist is inhuman and unempathic. Actually, being a neutral therapist means being especially human and empathic. The neutral therapist's empathic contact with the patient is the most extensive in that it includes not only contact with feelings and thoughts of which the patient is aware, but also contact with all those intolerable thoughts and feelings of which the patient prefers to be unaware. Such awareness in the therapist is possible only when the therapist remains, as Anna Freud (1) recommends, equidistant from the patient's id, ego and superego, that is equidistant from the forces generating the patient's psychic conflict. Such objectivity does not preclude warmth, rather it directly evolves from warm and authentic contact with the patient.

Freud (2) once observed:

It has not been possible to demonstrate . . that the human intellect has a particularly fine flair for the truth or that the human mind shows any special inclination for recognizing the truth. We have rather found, on the contrary, that our intellect very easily goes astray without any warning, and that nothing is more easily believed by us than what, without reference to the truth, comes to meet our wishful illusions. (p. 129)

It was probably with this observation in mind that Freud devised the term "psychical reality."

Strictly speaking, psychical reality refers to unconscious wishes and associated fantasies. An event is viewed not so much as it really is but as a person wishes to see it. What is familiar and expectable plays a large role in determining what a person sees and how he distinguishes real from unreal. Jacob Arlow (2), discussing the concept of psychical reality, explains that if a child at a certain stage of development were shown a movie of a person rising out of a swimming pool and landing on a diving board backward, the child would know something was wrong. That sequence is unreal; it differs from how the child's mind has integrated his experiences with objects in space. What he observed in the movie contradicts his previous reality testing.

Dr. Zawatsky is a third-year resident at the Sheppard and Enoch Pratt Hospital, Towson, Maryland. She is also a candidate at the Washington Psychoanalytic Institute. 
Reality testing in human relationships is even more complex. Interpersonal communications lead to more ambiguity. To a psychiatric patient the ambiguity is intensified in therapy especially where the therapist remains relatively anonymous and nonjudgemental. But it is in this "neutral" situation that the patient can begin to demonstrate his misperceptions of reality so that the conflicts behind his symptoms, behavioral troubles and character disturbances can be uncovered.

The patient is a patient because he continues to see his external reality in terms of previously expected or experienced infantile danger situations. Freud, and others since him, have reduced these situations to situations of object loss, the loss of love, castration anxiety, condemnation by one's own conscience, infantile paranoid terror, depressive helplessness, fragmentation of the self or loss of self in fusion. Because the world and the people in it are viewed in this way, the patient's existence is fraught with conflict. In my experience, the conflict always seems to come down at one time or another to a need/fear dilemma over intimacy. The patient wants to get close to other people but fears fusion, condemnation, abandonment, domination, castration, rejection, hurt or other catastrophes.

By maintaining an attitude of neutrality, the therapist can assist the patient to elaborate fully and work through his basic conflicts, which is the goal of therapy. As Freud (4) stated, “[our work] does not set out to make pathological reactions impossible, but to give the patient's ego freedom to decide one way or the other."' (p. 50).

To not be neutral, that is, constantly to "understand" and accept a patient's experience, as some therapists seem to recommend, encourages the patient to continue to view reality in his frightened and distorted ways. As a result, the patient feels entitled to his rage or depression or paranoid terror or fears of fusion. He is not motivated to explore his role in establishing and maintaining his psychical reality, his internal experience, his responsibility for his misery. Such sympathy discourages the patient's expression of hostility, so the opportunity to explore his hostility is lost.

Kohut (5) would like to blame the neutral therapist's lack of empathy for the patient's rage. In my experience, however, the patient's anger stems from confronting his conflicted, contradictory, anxiety-provoking ways of behaving, all of which are brought out with neutrality.

It is through neutrality that the therapist invites the patient to experience a wide range of emotions. Similarly, the therapist's neutrality gives the therapist freedom in himself to feel a wide range of feelings. Not being compelled to feel supportive, benevolent, reparative and always in good rapport with the patient, the therapist can allow himself freedom of internal experience (6). He can experience feelings which ordinarily may cause him guilt but which may ultimately benefit the patient. As Lesley Farber (7) has observed, there are some patients who only begin to make progress once the therapist has reached a state of despair. For example, one young woman patient complained to me about how 
difficult her work was, how she just could not do it. Finally, in my exasperation, I agreed with her. I suggested that she might be in over her head. The next week she told me that she had been able, after all, to do the assignment which she had said she could not do. My despair helped put the responsibility for her success in her hands. I think she realized that, ultimately, no therapist could do the work for her.

It is also through neutrality that the therapist can avoid the "burnout" syndrome (8). The neutral therapist does not need to consume psychic energy suppressing unacceptable feelings towards patients.

Hating the patient can be one of these "unacceptable" feelings the therapist tries to fight off. Winnicott (9) talks about hate in the countertransference. He points out that in certain stages with some patients the therapist's hate is actually sought by the patient and what then is needed is objective hate. He says, "If the patient seeks objective or justified hate, he must be able to reach it, else he cannot feel he can reach objective love.... It seems that some patients can believe in being loved only after reaching being hated," (p. 72).

Winnicott also describes the mother's hatred for her baby. The following are his reasons for the mother's hatred for her baby which I think also apply to the patient-therapist relationship:

A. The baby is not her own (mental) conception. . .

D. The baby is a danger to her body in pregnancy and at birth.

E. The baby is an interference with her private life, a challenge to preoccupation....

H. He is ruthless, treats her as scum, an unpaid servant, a slave.

I. She has to love him, excretions and all, at any rate at the beginning, till he has doubts about himself.

J. He tries to hurt her, periodically bites her, all in love.

$\mathrm{K}$. He shows disillusionment about her.

L. His excited love is cupboard love, so that having got what he wants he throws her away like orange peel.

M. The baby at first must dominate, he must be protected from coincidences, life must unfold at the baby's rate and all this needs his mother's continuous and detailed study. For instance, she must not be anxious when holding him, etc.

N. At first he does not know at all what she does or what she sacrifices for him. Especially he cannot allow for her hate.

$\mathrm{O}$. He is suspicious, refuses her good food, and makes her doubt herself, but eats well with his aunt.

P. After an awful morning with him she goes out, and he smiles at a stranger, who says: 'Isn't he sweet!'

Q. If she fails him at the start she knows he will pay her out for ever.

R. He excites her but frustrates-she mustn't eat him or trade in sex with him (p. 73-74). 
Winnicott explains how the mother has to be able to tolerate hating her baby without acting on it. Most importantly, if she fears what she may do and therefore cannot recognize her feelings of hatred, she falls back on masochism.

Winnicott goes on to say,

Sentimentality ... contains a denial of hate, and sentimentality in a mother is no good at all from the infant's point of view.

It seems doubtful whether a human child as he develops is capable of tolerating the full extent of his own hate in a sentimental environment. He needs hate to hate.

If this is true, a psychotic patient in analysis cannot be expected to tolerate his hate of the analyst unless the analyst can hate him (p. 74).

The usefulness of neutrality as well as the pitfalls of "compassion" in therapy to both the patient and the therapist became clear to me through my clinical experience with a patient whom I will call Jim, a 29 year old single male whom I encountered during his third psychiatric hospitalization. Admission diagnoses were Adjustment Disorder with Depressed Mood, and Borderline Personality Disorder.

The precipitating stressor was the loss of all his fingers due to frostbite several months prior to this hospitalization. Jim claimed that he had been assaulted by "rednecks" after leaving a gay bar, and left unconscious outdoors on a freezing night.

Jim was hospitalized for a period of weeks for amputation of his fingers and pedicle grafts from his abdomen. The latter procedure involved suturing his hands to his abdomen for several weeks to allow the grafts to vascularize. During this period, Jim was completely dependent, unable to feed himself or use the bathroom without complete assistance.

After his hands were detached from his abdomen, Jim was discharged from the hospital and moved into his parents' home. He did not think he could return to and live alone in his apartment or return to his office job and be able to do the work. After a few weeks, he invited his sister to take possession of his car and his apartment and told his out-patient therapist, who he had been seeing for several years, not to plan any future therapy sessions. When his mother found him hoarding Elavil tablets, she had Jim evaluated in an ER, where he was felt to be suicidal. He refused voluntary admission and was certified. He told the admitting resident that he was being hospitalized because he was having problems with an impaired body image and that his newly found homosexual identity was useless, since now no man would be interested in him. He also despaired over never being able to perform his clerical office job. Jim also was facing a court hearing for two Driving While Intoxicated charges about which he felt anxious. Most important in current stress, however, was impending reconstructive surgery. 
Jim had been depressed and anxious for as long as he could remember. $\mathrm{He}$ reported having been hospitalized at age twenty-five for two months and at age twenty-six for five months for depression, conflicts over dependency, alcoholism and sexual identity problems. Overlooking his alcohol abuse and two DWI charges, he described the three year interval between the second hospitalization and the loss of his fingers as the most stable period of his life.

Jim used the loss of his fingers to justify his life-long tendency to consider himself as unworthy, unlovable, undeserving, helpless and hopeless. He used his physical impairment to justify his chronic self-destructive, hateful, paranoid, despairing, angry experience in interpersonal relationships. Jim was a severely impaired person prior to the accident. After the accident he felt entitled to his symptoms and behavior. The loss of his fingers reified his distorted psychic reality and justified for him his fears of intimacy. He felt completely entitled to his hostility and rage.

A second consequence of Jim's physical injury was that unconsciously he felt guilty and responsible for his incident. After two months of therapy, he told me he regretted having had so much to drink the night of the accident and also blamed himself for staying out so late and leaving the bar alone. There is even some doubt as to whether he actually was accosted; the ER doctors who first treated him did not find evidence of any injury.

It seemed to me that the questions surrounding what actually happened on the night of Jim's accident were irrelevant. What mattered for Jim was what he believed, especially unconsciously, happened. Unconsciously, he felt guilty. $\mathrm{He}$ could not admit that to himself to a great enough extent, so his guilt remained not conscious enough. This guilt made him resistant to giving up the suffering of his illness. To Jim, his pain was atoning. This guilt, together with his feelings of entitlement to his behavior, culminated in the most oppositional, hateful, negativistic behavior I had encountered in my therapeutic experience. But each time I looked at Jim, I felt like I wanted to help him.

My compassion was a threat to Jim. Empathic contact terrified him, and this was demonstrated throughout his hospitalization. It was like the Groucho Marx joke about how he would not want to join a country club that would accept him as a member. Jim felt he was so unworthy that I either must have been pretending to like him or was a fool to spend time with him. Many times he insisted that it was just my job to be with him.

Over and over, he would attack various staff who tried to exhibit concern or offer hopeful words. Expression of concern would really terrify him, because it threatened to stimulate hope in him. He needed to convince himself that there was no hope for him. He would say, "All clinical contact is BS." He would say of the surgeon who was going to do reconstructive surgery, "He can't help me." He often said, "No one can help me," or "No one can be of use." Tuesday afternoons, before going to the hand clinic for physical therapy, he religiously would repeat, "The specialists don't know what to do to help me."

At two points during Jim's hospitalization, he took week-long signouts to 
another hospital for reconstructive surgery. A cleft was made in one hand during the first surgery and in the other hand during the second surgery. Jim's rejection of feeling helped or hopeful became most acute just prior to the surgeries.

To avoid developing any hope, Jim tried to sabotage the success of the surgeries. His first line of attack was to remain completely ignorant about what the surgeries would entail. Being able to prepare in one's mind for some future stress is a primary step in being able to tolerate and master that stress. Jim was making this preliminary step impossible: he refused meetings with the surgeon; he refused opportunities to ask questions which would help him mentally prepare himself. For example, after one meeting with his surgeon many months before any reconstructive surgery had been planned, the surgeon mentioned to Jim that one possibility of reconstructive work was to attach two toes to each hand. When reconstructive surgery (to create the clefts) was actually scheduled and in fact two weeks away, Jim thought that he would have his toes implanted on his hands. Not only had Jim been resisting to prepare himself for the stress involved with the surgery, but he had been resisting preparing for the wrong procedure. When he finally admitted to himself the nature of the actual surgery, I had to help him with his denial and resistance of an entirely different procedure which would give him some pincer movement.

After he returned from the second successful surgery, he seemed to be surprised that things had gone so smoothly. In fact, he felt so desperate about how well the surgery had gone that he tried to induce infection by refusing to take the antibiotics prescribed by the surgeon. When no infection developed, he cut off the plastic cast which covered the reconstructed area and melted it under hot water. His last resort was to deny the success of the surgery. For example, when Jim was seen picking up a bottle, something he could not do previously, he denied feeling encouraged by this new ability.

Jim sometimes saw empathy as overstimulating and perhaps seductive. Once, after a therapy session in which I tried to verbalize what he might be feeling concerning his upcoming second reconstructive surgery, as well to review his feelings about the previous surgery, he ran away from me while we were walking back to the hall from my office. In my need to make him feel wanted and cared for, I ran after him. The chase ended in the parking lot when he fell down, cutting his hands and lip. He returned to the hall, commenting in a somewhat flirtatious way, "what good legs Jonesie has." But within a few days, he was deeply entrenched in hostility and withdrawal. To be so pursued was simply too seductive, overstimulating and smothering for him.

Staff concern threatened Jim with feelings of indebtedness. He did not want to owe anybody anything because he felt so unable to give anything. For example, when he first came into the hospital, he was admitted to the short-term hall. While waiting for his hearing for the determination of whether or not he should be retained, he began to express doubts about being retained. He said he thought he would be released, and he said that he did not belong in the hospital. 
This must have frightened him, because he then overdosed on Elavil, ensuring his being retained. When he returned from the ICU to the hall, a mental health worker reminded Jim of the commitment he had made to him about telling a staff person if he felt suicidal. Jim's response was “I don't owe you anything." He then indirectly blamed a staff person for his suicide attempt. He said that he got the idea for tonguing medication from a staff person who, sensitive to issues of invasiveness, refused to do a mouth check on him. To owe anybody anything only intensified his feelings of worthlessness. So, no one could be of value to him.

Jim needed to see himself as a prisoner of other people, especially of people who he believed did not care about him. This protected him from the fear of letting anyone down or being let down himself. Of his hearing officer he said, "He is so smug. He makes me feel like they are going to do what they want, regardless of me." One day he said, "I feel a lot of apprehension when I first get up in the morning. I try not to look at the nurses and mental health workers as adversaries. But part of me just wants to shut it all down." After settling into the long term hall after being transferred from the short term hall, he said, "I feel more vulnerable here. I could resist more on the other hall. There is an unsafe element here." The unsafe element was apparently the enticement of getting close to other human beings.

Jim went to great lengths to keep himself securely in prison. Shortly after talking with me about his concern over being intoxicated the night of the accident, he put in a three-day notice. His mother responded by signing the forms necessary for certification. Jim responded by barricading himself in his room. This self-imprisonment neatly communicated his desperate need to remain hospitalized, as well as his fear of being hospitalized, close to other people.

Barricading himself in his room also put him in the position of power. By dominating and controlling the staff in this way, he could deflect his own attention away from his helplessness. Unfortunately, he also succeeded in deflecting the staff's attention from his helplessness as well. One nurse referred to his self-imposed imprisonment as his "shenanigans," which seemed to leave her free from having to deal with any of his frightening and overwhelming dependency needs. This too simple assessment of Jim's behavior angered him and made him feel more isolated and more fundamentally evil.

Once Jim was "rescued" from his self-imposed isolation, he was placed, with all good intention, in his first cold, wet sheet pack. This experience was frightening for him. While in the pack, he shouted, "Don't let them cut off my fingers!" over and over. The next day he told me that being in pack made him feel as if he had relived the skin graft procedure, with his hands sewn to his abdomen for so many weeks. This was the first I had heard of this part of the surgery. The sense of confinement and dependency his flow of words induced in me filled me with compassion for him. I felt compelled to try to make him feel better. 
Administratively, I did more for this patient than for any other. I called the drinking and driving monitor program and helped him get excused from the community service he was supposed to do as part of his DWI sentence. I arranged for him to get credit for AA meetings by attending the hospital's program. I also had many phone conversations with his surgeon, trying to orchestrate communication between Jim and his surgeon. I looked guiltily at my own fingers.

But, no matter what I did, it was never enough, or even useful to him. He always complained. Once he told me "I've been marked all my life, ridiculed by my friends - for my eczema; overprotected by my parents for my small size. Now I see myself as a freak. Other people laugh at me. I feel isolated."

Stanley Olinick (10), in his paper on the Negative Therapeutic Reaction, discusses the response of such patients to the expression of sympathy or compassion:

It is the greater tribute to the dissembling ability of these people, that it is so often accepted at face value that they are dogged by ill-fortune. This effect on the observer is unconsciously intended. No one must suspect the presence of forbidden wishes; consequently the wish is repressed and the prohibiting agency attributed to the fates. Success, or, for that matter, sympathy over failure will induce shame, guilt, depression, and resentment, for both threaten his narcissistic sense of perfection, and seductively confront him with his forbidden id derivatives. Therefore, he must suffer the strictures of his superego, or again reconstitute his defenses. The projection onto the fates having failed, it is once more projected, but perhaps this time onto a "persecuting" sympathizer (p. 543).

Clearly, the other members of the treatment team and I had become his "persecuting sympathizers." We stimulated in him all of his repressed, hopeful, excited wishes to love and be loved. But fulfillment of such wishes, according to his psychic reality, to his internal experience, was dangerous. To him, such intimacy was equivalent to emotional surrender to helpless, submissive, dependency.

He fought off this threat with his negativism. He refused to eat. He refused his Ensure. When on hall restriction he vociferously complained about not being able to go off the hall; however, once on staff escort, he complained that his physical appearance humiliated him too much to be seen off the hall, and he would isolate himself in his room. When his attending psychiatrist would hold morning rounds, he would say, "Jim?", to which Jim would reply, "No!'. Jim played his trump card when he announced that he had devised a way to to get kicked out of the hospital. He told us that he had not submitted any of his hospital bills to his insurance company for the past five months, and he said that unless we discharged him immediately, he would not submit the bills. When the hospital responded by submitting the bills for him, he countered that the 
insurance company paid him only, not the providers of care, and that he still controlled whether or not the hospital would get paid.

Olinick says that “. . . the patient's continuing negativism and projections must sooner or later impinge upon the most wholesomely developed analyst, however lightly and temporarily, or it is a sign that the instrument of empathic identification has given way to defenses,"' (p. 547). A re-evaluation during this most negativistic period helped me to regain my neutrality towards Jim. The re-evaluator was impressed with how much Jim had "bullied" the treatment team. He suggested that the patient's physical impairment should not be viewed as the only central problem and that Jim's readiness to use his physical disability to avoid talking about other matters should be a major focus in therapy. I began to become aware of all my feelings towards this patient, and I came to expect something in the way of work from him. I could give up trying to cure history. I was not going to be able to repair the loss of his fingers. Instead of trying to make him feel better, I would be in the position of actually fostering crises by confronting him with his defenses against feelings and impulses he found too unacceptable to admit into awareness.

My newly-found neutral position enabled me to approach the crucial territory of the loss of his fingers with less timidity. With my sympathy more in control, I could focus more clearly on the defensive use of his injury. He was using self-pity to keep in abeyance feelings of guilt and responsibility for his self-destructive behavior. Looking at his feelings of guilt about the accident was no longer felt to be like a sadistic attack on him but was an empathic response to feelings he himself had but kept in a split-off, dissociated state. This work around his role in the injury was crucial to a better state of integration for him and led to a decrease in unconscious self-punishment behavior. He no longer felt so desperately suicidal.

Neutrality also allowed better clarification and understanding of the various projected self and object representations Jim imposed on me. Reassuring Jim, in my compassion, that I really did care about him and that I did want to keep working with him led nowhere other than perhaps to a re-enactment of reactivated object relations. A more neutral response allowed Jim to experience this projected relationship to the point where he began to see its protective value. He began to see that rejecting people kept him from feeling any need for them.

It helped him to avoid his wishes for closeness and intimacy. This development was useful because it enabled him to leave the hospital and return to his original outpatient therapist. Prior to this hospitalization Jim felt threatened by intimacy with his outpatient therapist and he had rejected him. He has been working successfully with his outpatient therapist for over a year now.

My experience with Jim demonstrated to me the advantage of neutrality as opposed to a "compassionate" approach. Neutrality allowed for better understanding of the patient's psychic reality and better empathic contact with the patient. 


\section{REFERENCES}

1. Freud A: The Ego and Mechanisms of Defense, in The Writings of Anna Freud, Vol. 2. New York, International Universities Press, 1966

2. Freud S: Moses and Monotheism. Standard Edition, 23:7-137, 1939

3. Arlow J: Psychical Reality and Related Concepts. J Am Psychoanal Assoc 33:521-535, 1985

4. Freud S: The Ego and the Id. Standard Edition, 19:12-66, 1923

5. Kohut H: The Restoration of the Self. Madison, International Universities Press, 1977

6. Schafer R: The Analytic Attitude. New York, Basic Books, 1983

7. Farber L: The Therapeutic Despair. Psychiatry 21:7-20, 1958

8. Schulz CG: Personal communication, 1986

9. Winnicott D: Hate in the Countertransferance. Int J Psychoanal 30:69-74, 1949

10. Olinick S: The Negative Therapeutic Reaction. Int J Psychoanal 45:540-548, 1964 